\section{ARCHITECTURAL LITERARY ANALYSIS: READING “THE DEATH OF THE STREET" THROUGH BALLARD'S LITERATURE AND TRANCIK'S “LOST SPACE”}

\author{
Zeynep TUNA ULTAV*, T. Nur ÇAĞLAR**, \\ S. Bahar DURMAZ DRINKWATER***
}

Received: 29.10.2013; Son Metin: 05.11.2015

Keywords: Architectural research; literary fiction; literary analysis; interdisciplinary research; the death of the street; lost space; J.G. Ballard; High Rise; Concrete Island.

1. Havik $(2006,46)$ argues that literary descriptions of architectural and urban spaces are more influential in architectural or urban research than as directly instrumental design instruments due to the descriptive nature of literature that contradicts the prescriptive character of design disciplines.

2. Various urban settings have been stages for several well-known novels and stories, for example İstanbul as the setting of Pamuk's novels, London as the setting of Dicken's, Dublin as the setting of Joyce's, Paris as the setting of Proust's, Prague as the setting of Kafka's, St. Petersburg as the setting of Gogol's.

3. The research involves different scales of space both at the architectural and urban scale, such as the relationship between the high-rise and its setting, and the street pattern and its relationship to the plot. Therefore, in the following sections, "architectural/urban research" will be used to refer to their integration.

\footnotetext{
* Yaşar University, Department of Interior Architecture and Environmental Design, İzmir, TURKEY.

** TOBB University of Economy and Technology, Department of Architecture, Ankara, TURKEY.

*** Izmir University of Economics, Department of Architecture, İzmir, TURKEY.
}

\section{INTRODUCTION}

In the context of the interdisciplinary nature of architecture, this research aims to reveal the relationship between architectural research (1) and literary fiction. It is based on the idea that "architectural research has to go beyond a mere scientific model, and [...] has to consider literature and art" (Stein et al., 1990, 14). While literary fiction can verbally represent architectural and urban spaces as plot settings (2), architecture can utilize literary fiction as a supplementary instrument for both architectural and urban research (3). Scholars arguing for the necessity of such tools suggest that the mutual instrumental relationship between architecture and literature can be further studied. For example, Havik $(2006,43)$ asks "[w]hich methods of literary reflection are possible and instrumental in architectural research?" In support of this approach, Thomson $(1996,317)$ states "[h]istorically, the use of architecture in literature and, reciprocally, the serving of architecture by literature are enduring and writers have long used architecture as literary allegory, for character definition, to symbolize, and to contextualize". Regarding the use of architectural spaces within the medium of literature, the search for methods of exploring new associations with literary fiction can be regarded as beneficial. The importance of the role of literary texts within architectural/urban research is explained by Thomson $(1996,321)$ as follows:
"Our physical experience of architecture is apparently finite - bound by such constraints as time, place, and mobility. But literature offers us the opportunity to inhabit much different architecture in many different times and through this serves to strengthen our understanding of the chief poetic resonance of architecture - its latency, its capacity for shadowing forth the invisible and the illusory. This idea of latency is really the key in framing the portal between literature and architecture."

Acknowledging the fruitfulness of the interaction of architecture and urban planning with other spatial and non-spatial disciplines, this paper is 
4. Literary analysis could focus on different subjects, such as character, setting, plot, theme, dialogue, imagery, figures of speech, tone, rhyme and rhythm, or point of view. [https://owl.english.purdue.edu/owl/ resource/697/1/] and [http://www.germanna. edu/tutor/handouts/english/literary_analysis. pdf]

5. As Barlas $(1998,26)$ points out, "[b]y the late seventies it became a common practice to conserve the public nature of the street by means of 'pedestrianization' or other measures". Trancik's discourse can be seen as continuing this critical approach.

6. J.G. Ballard (1930 - 2009) was a British science fiction writer who wrote 18 novels, 18 short story collections (containing 123 stories in total), one autobiography and one book-length essay between 1960 and 2009. For more information about his life, see Stephenson (1991) and Ballard (2008). articulated as an interdisciplinary research. Literary fiction, in this respect, acts as a textual repertoire that enhances the relationships between collective memory and spaces. It creates new practices of understanding by penetrating into the layers of spatial meanings (Uz Sönmez, 2014).

In this context, this paper introduces a research methodology, namely architectural literary analysis, which uses literary fiction as an instrument for architectural/urban research. The method is based on "literary analysis" (4) in terms of searching for spatial clues within literary texts by focusing on the descriptions of the settings of novels with regard to several architectural theories and concepts. It aims at displaying the richness of socio-spatial knowledge within these texts, affluence richness that may systematically be conveyed to the architectural realm through the multiplication of similar studies.

This paper is structured so as to analyze two opposing theories in architectural/urban research through literary fiction. The first is Le Corbusier's (1967) modernist principles, suggesting "the death of the street" and proposing a new type of urban pattern, with free standing pavilions raised within the plots to create an urban pattern without the street. The second one is Roger Trancik's (1986) conceptualization of "lost space", which critiques the consequences of modernist principles and discusses the quality of modern urban space. Trancik (1986, vii) introduces five major factors contributing to the problem of lost space: "the automobile, the Modern Movement in architectural design (which can be interpreted as the principles of Corbusier), urban renewal and zoning policies, the dominance of private over public interests, and changes in land use in the inner city". Of the five, this research focuses on only two, rephrased as "high-rise landscapes" and "the edges of highways and surface parking lots".

Although not directly critiquing Le Corbusier's theory, "the death of the street", this paper suggests that Trancik's concept of "lost space" (5) can be regarded as taking a critical position to modernist principles. Furthermore, the analysis is also supported by J.G.Ballard's (6) novels in order to "find other ways of seeing, understanding and describing space" (Grillner and Hughes, 2006, 62). The written representation of the architectural and urban spaces in Ballard's literature provides a motive for analyzing two opposing visions: Le Corbusier's and Trancik's theories regarding the quality of architectural/urban space. In this context, both Trancik and Ballard are studied as commentators united by their critiques regarding "the death of the street" (Figure 1).

It is argued in this paper that Ballard's spatial narratives have parallels with critiques of "the death of the street" and support Trancik's (1986, vii) criticism of the modern city: that "the traditional structure of urban space

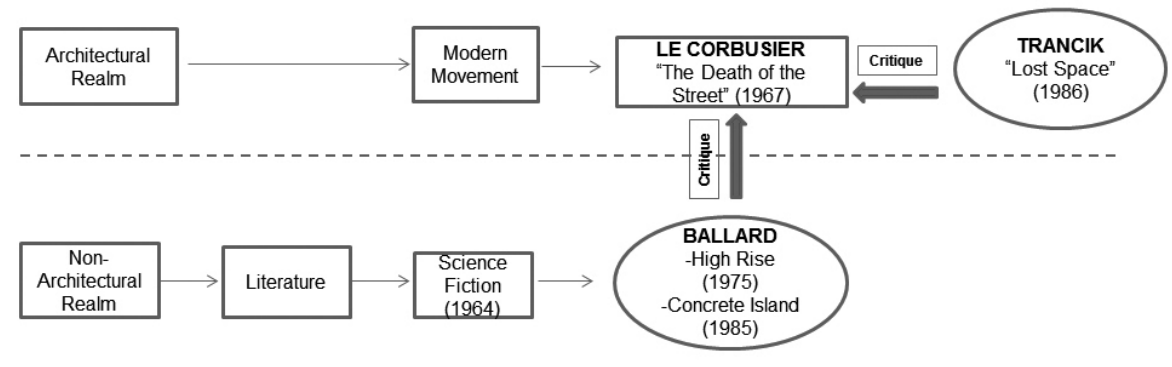


has been lost in most modern cities"; which Trancik terms "lost space". The representation of architectural/urban space in novels contributes to the reproduction of the knowledge of consequences of modernization at the architectural/urban scale. Hence, Ballard's spatial narratives can be interpreted as unintentional criticism of modernist principles, through the lens of a non-spatial discipline, i.e. literature.

\section{“THE DEATH OF THE STREET", "LOST SPACE" AND BALLARD'S LITERATURE}

Both Trancik and Ballard argue that the consequences of the modern movement, such as high-rise buildings and highways, destroy the traditional urban fabric and hence harm urban quality. Parallel to this critique, Berman (1988) also argues that the central feature of the situation of the modern is the destruction of everything we possess. The main source of such criticism can be traced back to Jane Jacobs's assertion that the threats to our world concern "unbuilding" cities rather than building them: "The ruthless, oversimplified, pseudo-city planning and pseudo-city design we get today is a form of 'unbuilding' cities. But although it was shaped and sanctified by reactionary theories actually glorifying the 'unbuilding' of cities, the practice and influence of this kind of planning today rests not on theory alone" (Jacobs, 1992, 408). In this context, Le Corbusier's "the death of the street" theory could be related to the motive of modernism, which is "unbuilding" cities, i.e. destroying the traditional pattern of the city. Le Corbusier $(1967,167)$ justifies his theory by emphasizing the disadvantages of traditional "corridor streets" that are "full of noise and dust and deprived of light". He proposes a new transportation network system to replace the old, "We have ceased being animals hunted down through a desert of stone. Man's own imminent death in the Great City has been replaced by the death of the street. An improvement!" $(1967,126)$. Le Corbusier $(1967,121)$ develops this argument in Radiant City as follows: "Our streets no longer work. Streets are an obsolete notion. There ought not to be such things as streets; we have to create something that will replace them. The 'Rights of Man' have been proclaimed".

7. Le Corbusier developed his ideas in the 'Contemporary City' utopia in his urban plans for the 'Radiant City,' which included sociological imagery as response to criticisms directed against previous plans (Gold, 1997, 44). Therefore "the death of the street" theory can also be included in the 'Radiant City' utopia. Although earlier, according to Barlas (2006, 123), Le Corbusier's "Plan Vision for Paris" (1925) held the same notions.

8. Gold $(1997,41)$ describes the 'Contemporary City' extensively. In his description, the central city was a rectangle containing two cross-axial super-highways. At the center were a six-level transport interchange, a meeting place of underground and main-line railways, road networks and, at the top, a landing-platform for 'aero-taxis'. 24 steel and glass skyscrapers of 60 stories served the city's civic and commercial needs around the center. These skyscrapers were raised on pilotis in order to leave unbroken greenery at ground level. In this respect, the general impression was that of a city in a park.
"The death of the street" is essentially inherent in Le Corbusier's utopian urban vision entitled 'A Contemporary City for Three Million Inhabitants'(7), in which he envisions the elimination of corridor streets, emphasizes instead the sovereignty of highways. Stating that "a city made for speed is made for success", Le Corbusier $(1987,179)$ defines the notion of "speed" as one of the most important elements in modern city planning. As highlighted by Gold (1997, 42), Le Corbusier redefines the function of the street, which, he states, has become "a machine for traffic, an apparatus for its circulation, a new organ, construction in itself and of the utmost importance, a sort of extended workshop" and "a factory for producing speed traffic" (8). Discussing Le Corbusier's "the death of the street" theory, Boyer $(2010,570)$ defines it as "resulting from failure of streets to perform their function in the contemporary city, and introducing speed to be classified as biological speed versus vehicular speeds and/or high-speed vehicles versus slow-moving objects". Barlas $(2006,121)$ points out that while Le Corbusier proposed the removal of the street due to its negative aspects such as "congestion, fumes, dust, lack of sunlight, dirt and most importantly the functional heterogeneity", he overlooked its positive aspects. 
9. Trancik, who is an urban planner as well as a landscape architect, has established his discourse mainly on the criticism of modern urban planning.

10. Trancik cites Peterson (1980), who described "space as conceivable and antispace [lost space] as inconceivable volume. Space can be measured; it has definite and perceivable boundaries; it is discontinuous in principle, closed, static, yet serial in composition. Anti-space, on the other hand, is shapeless, continuous, lacking perceivable edges of form" (Peterson, 1980, 88-9).

11. Halliday $(1979,8)$ asserts that the 1970 s, which can be considered as the initial years of New Wave fiction, show a change of emphasis from the purely physical environment to the social environment.
A contrasting view, critical of the destructive mode of modern architecture and planning, resulting in the "unbuilding of cities" is most clearly articulated by Trancik in his book, Finding Lost Space (1986) (9). As a major source of critical theories on the modern city, Trancik's discourse has a significant value as an inclusive critique of modern space, which Trancik terms "lost space" and Steve Peterson terms "anti-space" (10). In a way, the result of this action, defined as the "unbuilding of cities", is "lost space", which has none of the essential physical and socio-cultural characteristics of traditional public space, such as diversity, accessibility, identity or social life. The expression "lost space", employed in Trancik's critique, means "lost" among the city's multi-story buildings, referring to any space that cannot be used by city dwellers due to its location on the edges of highways that connect suburbs and city centers. He further defines "lost space" as follows:

"Lost space is the leftover unstructured landscape at the base of high-rise towers or the unused sunken plaza away from the flow of pedestrian activity in the city. Lost spaces are the surface parking lots that ring the urban core of almost all American cities and sever the connection between the commercial center and residential areas. They are the no-man's-lands along the edges of freeways that nobody cares about maintaining, much less using. Lost spaces are also the abandoned waterfronts, train yards, vacated military sites, and industrial complexes that have moved out to the suburbs for easier access and perhaps lower taxes. They are the vacant blight-clearance sites remnants of the urban-renewal days - that were, for a multitude of reasons, never redeveloped..." (Trancik, 1986, 2-3).

Trancik points out that modern urban planning does not value the design of vacant urban spaces that result in the disappearance of the concept of place as understood in traditional, urban planning. His criticism seems directed at "the death of the street", as Le Corbusier's proposal destroys street life by eliminating traditional street patterns, which then results in a loss of diversity and richness of public life in urban space.

Ballard's literature provides a productive basis to establish parallels with Trancik's criticism of the modern landscape as represented through Le Corbusier's "the death of the street" theory. Ballard is an important author within the New Wave movement, a branch of science fiction that first emerged in 1964 with Michael Morcock's publication of New Worlds magazine. As well as his impact on the development of science fiction, Ballard has made a widely-accepted impact on architectural research, employing spatial elements "to understand the city as narrative" (Sellars, 2009 , 86). In addition to the overall sensitivity towards spatial issues in his works, Ballard has contributed significant critiques of modern architectural space.

Another reason for studying Ballard is that his novels define the physical environment as part of the social environment (11). His New Wave fiction asserts that "our successors from another planet could reconstitute the psychology of the people on this planet from its architecture, if every member of the human race were to vanish" (Ballard, 1984, 44), thus presenting us with landscapes that are apparently extrapolative in nature (Malmgren, 1991, 124). Ballard juxtaposes the physical environment and the social environment in his novels, "A new social type was being created by the apartment building, a cool, unemotional personality impervious to the psychological pressures of high rise life, with minimal needs for privacy, who thrived like an advanced species of machine in the neutral atmosphere" (Ballard, 1975, 35). 
According to Taylor $(2002,95)$, Ballard's characters appear as alienated bodies reacting against the new modern situation, "the protagonists find themselves in situations where their subjectivity is altered by changes in the built environment". In this respect, Ballard $(1996,197)$ himself defines his own understanding of science fiction as follows:

"Firstly, I think science fiction should turn its back on space, on interstellar travel, extraterrestrial life forms, galactic wars and the overlap of these ideas that spreads across the margins of nine-tenths of magazine s-f [...] The biggest developments of the immediate future will take place, not on the Moon or Mars, but on Earth, and its inner space, not outer, that needs to be explored. The only truly alien planet is Earth..."

Among Ballard's eighteen novels, High Rise (1975) and Concrete Island (1985) have been selected in this research to exemplify his criticism of the modern city. The former suggests that lost space occurs due to the high rise landscape, while the latter discusses lost space occurring at the edges of highways and surface parking lots.

The high-rise building in the novel constructs its object as a self-sufficient hi-tech communal skyscraper, defined by Gasiorek $(2005,120)$ as "the emblem of a modernist architecture". The main object of the novel High Rise is a communally-owned forty-story apartment building on London's periphery. It functions as a small "vertical city", with its one thousand apartments, several pools, shopping malls, a gymnasium, a small movie theatre, a school, a private bank, fast elevators and other facilities, providing habitation for around two thousand urban dwellers. The main theme of the novel is that this seemingly self-sufficient, perfect, peaceful vertical city is eventually revealed to be a nightmare, in which the theme of the transformation of the inner landscape by the outer landscape is emphasized (12). The novel is structured around the different perceptions of modern life of the three protagonists in the building: Laing, a physician; Wilder, a television producer, and Royal, the building's architect.

The novel Concrete Island considers the plight of the trapped individual, by taking a particular piece of land as its setting. It is the story of a 35 year old architect (13), Robert Maitland, who falls into a small traffic island after an accident in his Jaguar. The protagonist is then forced to remain in this piece of land, the setting of the plot. Ballard utilizes this land_as a metaphor for the feeling of isolation caused by modernized urban life. Highways represent isolation as much as modern life does: “... You've got a hundred times more hang-ups. Your wife, this woman doctor - you were on an island long before you crashed here" (Ballard, 1985, 141). The setting of

12. The argument for the transformation of inner landscape by changes in the natural environment has been put forward by Taylor. See J. Taylor (2002). Ballard explains the relationship between landscape and human psychology as follows: "These are stories of huge psychic transformations, and I use this external transformation of the landscape to reflect, and marry with, the internal transformation, the psychological transformation, of the characters" (as cited in Pringle, 1984, xxii-xxiii).

13. In both novels, the protagonists are architects, which proves Ballard's intention to put the emphasis on the built environment created by architects. the novel, as a left-over space between highways, can be defined as "lost space", with the adjective "concrete" referring not only to the "island" setting of the novel but to the representation of the whole modern urban landscape. Maitland, suddenly finding himself deprived of his comfortable modern life, discovers his real ego in this landscape, and encounters different kinds of lives in the space under a highway.

As discussed so far, both of these novels are important in the sense that they are the most discussed of Ballard's works, and both construct their plot so as to highlight the destructive effects of modernist principles.

Through architectural literary analysis, the following sections will highlight the parallels between the criticisms contained in Ballard's literature and those of Trancik. 
14. The high-rise landscape within architectural discourse can be exemplified through three significant critiques by Scully, Tafuri and Mumford. Scully (1986), who describes the result of such a landscape as the destruction of the city, sees the high-rise block as an attempt to substitute the city itself. He sees the skyscraper as a "blind destructive force eroding the very street fabric it needs as a foil for its own individual and commercial ends" (as cited in Levine, 2003). Tafuri, in a parallel reading, evaluates the high-rise as a city within a city. According to him, this "gigantic machine", being able to offer all the services that a city can, does not need to communicate with its urban context; for this reason, it is "anti-urban" (Tafuri, 1979, 503). Mumford $(1953,231)$ also criticizes high-rises for the low-quality open spaces that are inevitably created around them: "Let us not be deceived by the appearance of the spatial openness that can be achieved by crowding many families into fifteen-story apartment houses. Abstract visual open spaces are not the equivalent of functional open space that may be used as playgrounds and private gardens..."

15. It is possible to interpret the use of the architectural analogy by Ballard in two ways: the first is that the architecture of the "Unité", with its utopian structure, presents Ballard with a strong instrument to construct his model on the characteristics of a predefined building; the second is that any reader that has distinguished the critique that the building is subject to through his/ her knowledge of architectural history may establish parallels to understand the dystopian picture intended by Ballard.
All late $20^{\text {th }}$ century works, the theories and novels discussed here are products of different decades: The Death of the Street in 1967, Finding Lost Space in 1986, High Rise in 1975 and Concrete Island in 1985. They each take a position either criticizing or supporting the principles of the Modern Movement in architecture and urbanism. It is important to note, however, that in spite of their different stances these theories and novels share a number of features, as they all consider the mutual relationship between physical and social space. Hence, by taking this approach, this research is able to shed light on the dynamics and relationships between several decades of the late twentieth century in terms of the importance given to the street pattern and public realm.

\section{BALLARD'S LITERATURE AS AN INSTRUMENT FOR ARCHITECTURAL LITERARY ANALYSIS}

\section{"High-rise Landscape" in Ballard's Literature}

Le Corbusier's highly influential theory of "the death of the street" can be regarded as having initiated the sprawl of high-rise landscapes. His main principle for eliminating traditional streets required the replacement of existing urban patterns, both the buildings and streets, with high-rises located in individual plots, also named as "free-standing pavilions" (14). As Le Corbusier states, "we must increase the open spaces and diminish the distances to be covered. Therefore, the center of the city must be constructed vertically" (Le Corbusier, 1987, 167).

This research argues that rather than having a positive effect on cities, Corbusier's principles for building healthy living and working environments destroyed the urban fabric due to its promotion of a high-rise landscape, functional segregation, automobile-dependence and resulting highways. Architectural critic Scully (2003) describes the modernist glass skyscraper as a blind destructive force eroding the very street fabric it needs as a foil for its own individual and commercial ends. According to Woudstra (2000), this approach overemphasizes the built form, and damages the sense of place by showing an interest in self-sufficient buildings, machines for living, rather than the landscape.

It is possible to suggest that there are strong parallels between High Rise and Le Corbusier's Unité d'Habitation, the influential apartment building model through which he displays his modernist principles. The apartment building described in Ballard's literature can be interpreted as the object of Le Corbusier's Modernist construct. These parallels were also proposed by Sellars $(2007,85)$ when he describes the high-rise building in the novel as "a Neo-Corbusian residential building". The parallels between these buildings - one constructed and the other literary - can be listed as follows: their self-sufficient nature, their roles as small urban pieces within a larger urban ensemble and their accommodation of different types of units with spaces reserved for common activities. The architectural construct of the "Unité" appears in Ballard's novel in a similar way in terms of the building's function, content and scale (15). In this sense, the High Rise - just like the Unité - offers a communal way of living in which all essential units are found within the building. Ballard $(1975,8)$ implies inspiration from Le Corbusier by indicating that the parking spaces and concrete plazas are located on the ground floor of the building within and around the spaces created by the raised "pilotis" and also by indicating the multifunctional design of the building. However, it is also important to note that "Unite" is 
raised on the pilotis, by providing just empty space on the unused ground floor. Nevertheless, it is an important similarity in terms of the nature of the design, if not the function.

“... For all its size, the high-rise contained an impressive range of services. The entire $10^{\text {th }}$ floor was given over to a wide concourse, as large as an aircraft carrier's flight-deck, which contained a supermarket, bank and hairdressing salon, a swimming-pool and gymnasium, a well-stocked liquor store and a junior school for the few young children in the block. High above Laing, on the 35th floor, was a second, smaller swimming-pool, a sauna and a restaurant. Delighted by this glut of conveniences, Laing made less and less effort to leave the building. He unpacked his record-collection and played himself into his new life, sitting on his balcony and gazing across the parking-lots and concrete plazas below him" (Ballard, 1975, 9).

Ballard's High Rise has some spatial representations with the characteristics of Trancik's lost space concept. The novel underlines two issues: first, the effect of the high-rise landscape on the urban scale, as well as the urban fabric; second, the dysfunctionality of open spaces planned among these high-rise buildings that weaken social life.

The change in urban scale created by the high-rise causes the displacement of the human scale as well as the destruction of urban life - that is, the social function of the street. Two urban designers and academics, Jacobs and Appleyard (1987) criticize this new urban fabric for lacking diversity, spontaneity and surprise, particularly for pedestrians. For such spaces, Kallus $(2001,146)$ proposes "urban design tactics" to include "meaningful references to human behavior as related to the needs of real people and their everyday lives", as opposed to abstract spatial volumetric organization. More than any other critic, Trancik characterizes high-rises as isolated "superblocks" that affect the urban scale and the micro-cities created through them as lacking the capability to substitute for genuine urban life. According to Trancik $(1986,12)$, the social functioning of the spatial organization of urban life should be given a much higher priority:
“Isolated 'superblocks' formed by urban-renewal plans closed off historic streets, drastically affecting the scale of the city. Abstract notions of compatible uses created urban areas that could no longer accommodate physical or social diversity, and that, therefore, were no longer truly urban. Both zoning and urban renewal substituted functional for spatial order and failed to recognize the importance of spatial order to social function" (Trancik, 1986, 12).

Ballard and Trancik's criticism of modernist projects also have parallels in terms of scale. Ballard's main concern with high-rise buildings is that the voids created between them are so enormous and dysfunctional that they subvert the urban dweller's perception of scale, causing a loss of trust in the scale of the environment (Ballard, 1975):

"The immense volume of open space that separated the building from the neighboring high-rise, a quarter of a mile away unsettled his sense of balance. At times he felt that he was living in the gondola of a ferris wheel permanently suspended three hundred feet above the ground" (Ballard, $1975,8)$.

Being "suspended three hundred feet above the ground" means being detached and disaffiliated from the earth in reference to the Unité d'Habitation, which is supported on pilotis to allow pedestrian flow beneath. This emphasis on unused urban space in both designs, transforms their scale of the spatial experience. Thus, Ballard's criticism is the same as Trancik's of "lost space". 
16. Suggested by André Breton in his novel Nadja (1928 as cited in Frisby, 2003, 57).
Le Corbusier proposes a new urban life by providing different functions within a single building and suggests that streets have lost importance and are in fact the source of many urban problems. Hence, he proposes "the death of the street" against supporters of the street as being "the only valid field of experience"(16). Although his theory was influential in terms of shaping the contemporary built environment, it has been the target of much criticism, as "being simplistic and obsessively directed towards the control of the living environment irrespective of people's needs, without sympathy and sensitivity towards people, places" (Woudstra, 2000, 150). Gehl $(1987,16,47)$ also argues that streets are very important for the social life of the city, which he calls "the life between the buildings". He criticizes "the death of the street", characterizing this as being the replacement of "streets and squares" by "roads, paths, and endless grass lawns". Streets are places not only for "merely pedestrian traffic or recreational or social activities", but also for "the entire spectrum of activities, which combine to make communal spaces in cities and residential areas meaningful and attractive" (Gehl, 1987).

Trancik's criticism also has parallels with Gehl's argument that a highrise building as a mere architectural object does not communicate with its surroundings. He defines the vastness of outdoor spaces created in between - as proposed by Le Corbusier - as lost space, because they are designed without regard for people's needs or daily routines. Additionally, and more importantly, high-rise towers themselves and lives within them are also distanced from urban life. In this respect, there are parallels between Trancik and Ballard in their criticism of the way in which high-rises transform the urban scale and create useless vast open spaces within urban landscapes. Ballard's novel employs a range of remarkable metaphors in order to represent high-rises. One illustration of such a metaphor is the "nervousness" of the sun in waking the high-rise "giants", an act which in itself is portrayed as a confrontation. This metaphor is extended to emphasize the uselessness of the plazas and parking lots:

"The high-rises seemed almost to challenge the sun itself - Anthony Royal and the architects who had designed the complex could not have foreseen the drama of confrontation each morning between these concrete slabs and the rising sun. It was only fitting that the sun first appeared between the legs of the apartment blocks, raising itself over the horizon as if nervous of waking this line of giants. During the morning, from his office on the top floor of the medical school, Laing would watch their shadows swing across the parking-lots and empty plazas of the project, sluice-gates opening to admit the day. For all his reservations, Laing was the first to concede that these huge buildings had won their attempt to colonize the sky" (Ballard, 1975, 19).

As demonstrated so far, the construction of high rise landscapes mainly inspired by Corbusier's theory of "the death of the street" is critiqued in Ballard's novels. Hence, Ballard's literature lends support to the anti-thesis of "the death of the street", of favoring streets as the essential life blood of cities (Jacobs, 1992). The following discussion focuses on another problem that results in lost spaces, namely "edges of highways and surface parking lots".

\section{Edges of Highways and Surface Parking Lots in Ballard's Literature}

The principles of modern urban planning support functional segregation and thus the formation of suburbs, which are connected to the city by highways and major roads. Segregation contributes to the decentralization 
of housing towards the peripheries of cities, resulting in suburban development. The chain of consequences created by functional segregation begins with the emergence of highways connecting the segregated districts, which in turn results in dependence upon automobiles and the open areas required for their storage. Le Corbusier $(2007,185)$, however, supports the use of automobiles, "So let us put the Parthenon and the automobile on show to make it clear that it is a question here, in different domains, of two products of selection, the one having reached its outcome, the other still progressing. This ennobles the automobile". Le Corbusier's emphasis on suburban development concurs with his vision of "the death of the street", which would inevitably involve replacing streets:
"The cities will be part of the country: I shall live 30 miles from my office in one direction, under a pine tree; my secretary will live 30 miles away from it too. In the other direction, under another pine tree. We shall both have our own car [...] We shall use up tires. Wear out road surfaces and gears, consume oil and gasoline. All of which will necessitate a great deal of work... enough for all" (Le Corbusier, 1967, 142).

Functional segregation and the resulting use of automobile have been criticized by many researchers for harming urban quality and the social life of cities. Jacobs ([1961] 1992, 408), for example, criticizes it as an "oversimplified" approach that "goes to the problem from the wrong end", as the segregation itself becomes a problem. The solution to this problem, the automobile, then becomes a problem itself.

The widespread use of automobiles to allow rapid movement between different parts of the city is criticized as a "purely movement experience rather than a social one" (Carmona et al., 2010, 84). Carmona $(2010,125)$ also adds that "he [Trancik] argues the blame for creating lost spaces lies squarely with the car, urban renewal, the privatization of public space, functional separation of uses, and with the Modern Movement" (17). Lefebvre has also pointed out the anti-socializing impact of automobiles on the users of the city:

"[C]ity life is subtly but profoundly changed, sacrificed to that abstract space where cars circulate like so many atomic particles [...] [T] he driver is concerned only with steering himself to his destination, and in looking about sees only what he needs to see for that purpose; he thus perceives only his route, which has been materialized, mechanized, and technicized, and he sees it from one angle only - that of its functionality: speed, readability, facility" (18) (Lefebvre, 1991 cited in Carmona et al., 2010, 202).

17. There are other critics who have read modernist urban planning with a similar critique. Carmona mentions LoukaitouSideris, who writes about 'Cracks in the City', which he describes as "in-between spaces, residual, under-utilized and often deteriorating" (1996, as cited in Carmona, 2010, 125). The design parallel of Trancik's criticism can be seen in New Urbanist proposals that sought to create community through designing public spaces that attract people: "They wish to recreate a street life, so that people do not feel the need to withdraw into the built environment" (Meredith, 2003, 486).

18. Virilio $(1984,546)$ claims that speed replaces "the distances of space and time, abolishes the notion of physical dimension", suddenly returning to a scale that resists any kind of temporal or spatial measurement, and "suddenly, speed returns to a primary scale which resists any kind of measurement, whether it be temporal or spatial".
Similarly, Trancik also criticizes the results of functional segregation within Le Corbusier's utopian vision, which necessitates "an increased dependence on the automobile" (Trancik, 1986, 4) and thus the existence of the element of the highway as a connection instrument. Trancik argues that highway construction, dating back to the 1940s, can also be considered "lost space". Trancik's main criticism is that traditional vehicular links are interrupted, and he argues that walking experience has become a "disjointed and disorienting" experience:

"As these highways cut through the cities, they created huge areas of lost space. Like urban renewal, the highway projects forced tens of thousands of people to relocate, creating profound traumas which resulted from social disorientation. Mobility, motion, and the automobile became instruments for isolation" (Trancik, 1986, 6).

He points out that highways destroy life on the streets and kill the unique identity of a city, urban vitality and diversity. Accordingly, Trancik's 
criticism of highways can be interpreted as an indirect criticism of Le Corbusier's vision.

In addition to these criticisms from the realms of architecture and urban planning, it is also possible to view Ballard's literature as a criticism of highways. In his literature, specifically Concrete Island, Ballard often uses the image of the highway between the metropolis and its suburbs in the periphery as an instrument to represent the urban landscape. He uses this visual potential of highways to create a landscape in which modern city planning is demonstrated by transportation networks.

Ballard argues that although highways and automobiles are put forward as a solution to decrease the travel times in cities, highways actually increase the problem exponentially, by lengthening distances and journey times. In Concrete Island, most of the plot takes place within this highway landscape, which provides a very dominant spatial setting. That is, in using the automobile as the symbol of modern life, Concrete Island exploits the highway as the plot as well as the stage of the novel. The landscape of the six-lane highway, along which "the traffic moved on all sides of the island", (Ballard, 1985, 73) is portrayed in the following excerpt:

"Shielding his eyes from the sunlight, Maitland saw that he had crashed into a small traffic island, some two hundred yards long and triangular in shape, that lay in the waste ground between three converging motorway routes [...] Supported on massive concrete pillars, its six lanes of traffic were sealed from view by the corrugated metal splash-guards installed to protect the vehicles below (Ballard, 1985, 11-2).

In this world, the scale of the highways, supported by massive columns is shown by the fact that they are separated by spaces of approximately 180 meters of arid ground. Ballard also points out that this highway system completely ignores the history that once existed beneath it. He uses the phenomenon of speed to reveal his critical stance. It is the highway, and the speed it allows, which causes Maitland's isolation on the island. Although there are drivers trying to get a glimpse of Maitland, it is impossible to help him because they cannot perceive anything clearly at their speed, with their focus fixed on the route and its junctions and signposts (Ballard, 1985). Ballard's descriptions can be interpreted as a critique of Corbusier's notions of speed, since people are not even aware of Maitland's existence due to speed, thereby leaving him in this isolated landscape as an imprisoned individual.

The parking lots that result from the excessive use of automobiles between urban centers and suburbs are targets for both Trancik's and Ballard's criticism. Like Trancik's $(1985,12)$ definition of "undeveloped space given over to parking lots in wait for development", Ballard uses the concept of "empty parking lots", portraying these empty open spaces as having no consideration for the public life of the modern urban environment. The transformation of urban space through empty parking spaces, as "lost spaces" as a consequence of the highway landscape, also has parallels with the vast amounts of open space created under high-rises. In Concrete Island (1985), the "empty park areas" are emphasized in order to describe the Maitland's worldview, which is contrasted with Catherine's, his wife. The novel portrays such areas, which contribute nothing to the richness of urban life, as an unnecessary component of the urban landscape:

"... It was no coincidence that when he had first taken Helen Fairfax to the south of France they had gone straight to La Grande Motte, the futuristic resort complex on the coast a few miles away. Helen had quietly hated 
the hard, affectless architecture with its stylized concrete surfaces, nervous of Maitland's buoyant humor. At the time he had found himself wishing that Catherine were with him - she would have liked the ziggurat hotels and apartment houses, and the vast, empty parking lots laid down by the planners years before any tourist would arrive to park their cars, like a city abandoned in advance of itself" (Ballard, 1985, 65).

In this extract, two contradictory situations are described in order to emphasize the role played by modern urban planning in the creation of such monotonous landscapes. The first is that Helen, Maitland's lover, hates modernism and modern built environments. The second is that Catherine, his wife, likes the artificial products of modern architecture with "its concrete stylized faces" (Ballard, 1985, 65). By revealing Catherine's affection for empty parking lots, Ballard associates them with the artificial quality of modern architecture, and implies criticism of both. There are several occasions throughout the story in which Catherine and Helen are contrasted. As Maitland's wife, Catherine represents "the system" by supporting the visual elements of the modernist landscape supported by capitalism; Helen, the lover, represents the visual codes of the antimodernist physical environment.

Trancik's and Ballard's arguments can thus be interpreted as parallel criticisms of the modern highway landscape, in opposition to the notion of "speed", and the consequent "death of the street" due to highways. Ballard also employs this critique in terms of both the highway object and its results (automobiles and speed).

\section{CONCLUDING REMARKS}

This research was based on the hypothesis that written representations of architectural/urban space within literary fiction have played a similar role to architectural criticisms of the late $20^{\text {th }}$ century in evaluating modernist principles, and can therefore be used as data in architectural research.

Main concluding remarks are summarized and evaluated further below:

1. "Architectural Literary Analysis", employed in this paper, is a legitimate research methodology in both architecture/urban and literature/literary fiction.

2. This research methodology can contribute to both architectural and non-architectural realms.

3. Architectural literary analysis provides a reciprocal relationship as a research methodology for architectural/urban research and literature/ literary fiction.

Regarding the first remark, the paper introduced a research methodology and theorized the relationship between architecture and literature at different levels. Although there are several other studies that analyze spatial narratives in novels through the lenses of architecture, one can hardly find any comprehensive theorizations of the relationship between architecture and literary fiction. In OASE 70, the editors, Grafe, Havik, and Maaskant (2006), describe the method of such analysis as "using literary materials and techniques". Havik (2014) later defines the whole urban reading practice as "urban literacy". One conference focusing on the

19. The full name of the conference is

"Architexture 2008: Textual and Architectural Spaces". For more information, see [http:// iawis.org/architexture-2008-textual-andarchitectural-spaces/] relationship between architecture and literature has termed the concept "Architexture" (19), which implies that a new term was needed to describe this research area. In the two other reference books by Tümer $(1981 ; 1984)$, 
20. One existing research laboratory, called "LabLitArch", which is supervised by architect/ author/ illustrator Matteo Pericoli, exemplifies the variety of such audiences. See [http://lablitarch.com/].

21. It is possible to come across workshops that explore the relationship between architecture and literary fiction in architectural literature, such as Thomson's (1996) Memory Palace, Uz Sönmez's workshop about Taşkışla, where students wrote about their experience in the building (2006), and Antoniades's workshop within a second-year architectural studio at UT Arlington in 1984 (Antoniades, 1992). It should also be noted that Italo Calvino's well-known novel Invisible Cities is considered as one of the favorite sources to refer to.
Figure 2. Architectural literary analysis as a research method in both architectural and non-architectural realms. the author does not coin any terms for the method of analyzing literary texts. Spurr (2012), however, suggests that the study of relations between architecture and literature needs to go beyond mere analogy to develop a profound architectural analysis. The present research suggests naming the methodology "architectural literary analysis".

As discussed throughout this research, architectural literary analysis offers new perspectives that conventional architectural criticism is unable to provide. As seen in Ballard's architectural literary analysis, the discussion becomes more influential through combing the complementary viewpoints of architecture and literary fiction, charged with different perceptions (Tümer, 1997; Thomson, 1996). Although there are many parallels between Trancik's discourse and Ballard's, the latter's is supported by illustrating a possible future showing the consequences of the destructive effects of modern urban life. As a part of the New Wave Movement, Ballard does not endeavor to create new realities; rather, he decodes the conditions of the recent past and the present into a future perspective. He establishes his criticism through the exaggeration of these conditions. For example, in High Rise, the psychological scene is exaggerated, and the alienated characters find themselves amidst violence and crime. Such exaggerated realities are designed to increase the impact on students and the wider public, as discussed below regarding the paper's second remark. Since literary fiction has a richer elaborated style and contextualizes abstract criticisms through concrete examples, the message becomes clearer. In the case of Ballard's novels, the message is conveyed through the physical qualities of the high rise building, and the psychology of its residents, as well as through the physical qualities of urban space created among the highways and the psychology of Maitland.

This paper's second remark is that the method of architectural literary analysis contributes to both architectural and non-architectural realms since it has the potential to address the audiences of both (Figure 2). The first, the audience of architecture (education, research and practice), includes academics and students, researchers and practicing architects (20). In the educational realm, the products of architectural literary analysis, i.e. research papers, reports, theses and critiques of architectural theories, can be instrumental as a part of curricula through lectures and/

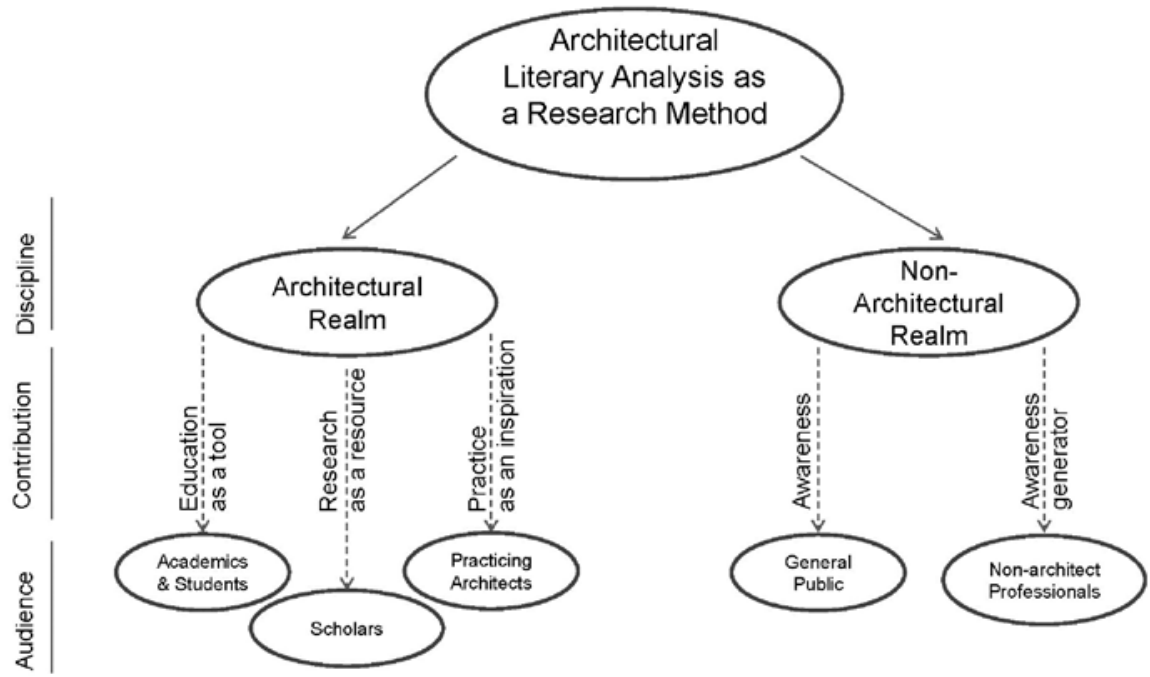


or workshops (21). Architectural/urban historians can employ architectural literary analysis in their introduction of historical periods and styles, and/ or the criticism of these periods (e.g. the critique of modern architecture) as a supplementary source to the "vocabulary of specialist knowledge", which is "formal and constructional" (Shonfield, 2000). The products of architectural literary analysis can also provide inspirational spatial descriptions for architectural studio courses. As for the research realm, architectural literary analysis can be used by scholars as reference sources in theses, research papers, reports, etc. in order to support the argument of their studies. Finally, in the practical realm of architecture, the utilization of architectural literary analysis is twofold. The critical aspects of such research can be considered as suggestions for the design of architectural products (i.e. how not to build), and futuristic spatial representations can be sources of inspiration. The descriptive aspect inherent in literature serves as a prescriptive tool for architectural practice.

As for the non-architectural realm, architectural literary analysis presents in-depth analysis for the general public and non-architect professionals who may read Ballard -and perhaps even Trancik - without being able to derive architectural interpretations. Literary fiction, as a non-academic text, is more likely to attract the attention of non-architect audiences, allowing criticism to be easily be absorbed into popular culture. Thus, architectural literary analysis could introduce an awareness of architectural and urban critiques to a wider society. Another non-architectural audience may be professionals, such as literary critics, authors, film makers, graphic novelists, graphic designers, sociologists or psychologists. Architectural literary analysis would make these professionals familiar with architectural terminology and widen their horizons in terms of architectural critiques, thus presenting methods and terminology to make architectural/urban criticisms. Consequently, the product of architectural literary analysis could be a more accessible medium for a non-architect unfamiliar with specialist architectural literature.

The third remark concerns the reciprocal relationship between architectural/urban research and the research of literary fiction/literature. As well as the use of the literary text as a critique supporting architectural criticism, literary critics can also use architectural theory to read/analyze/ critique literary texts (Figures 3 and 4). As Tutaş (2006) explains, literary critics employ linguistic, semantic and stylistic analysis in criticism of literary texts. As Bryden (2012) notes, "literary theory has long drawn

Figure 3. Architectural literary analysis: literary fiction as a support tool to analyze and criticize an architectural theory
Figure 4. Architectural literary analysis: literary fiction as the object of architectural criticism
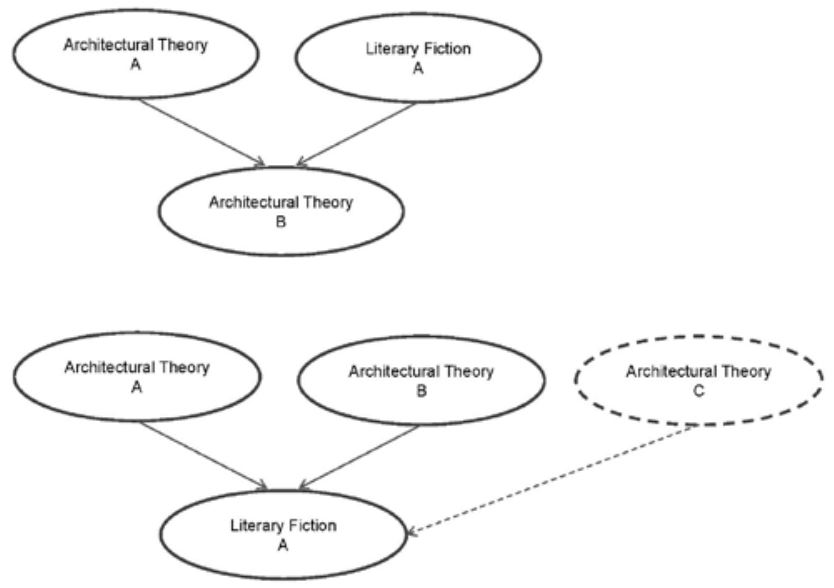
22. For further explanation of these subgenres within science fiction, see Saatçioğlu (2002). on spatial terminology, such as structure and form". In this context, architectural literary analysis could provide more familiarity with spatial terminology, which would enrich literary critics' semantic analysis, enabling them to overlap meaning layers in the architectural and nonarchitectural realms.

Further research could pursue the focus of the tripartite relationship between modernity, architecture and literary fiction, specifically science fiction, as a literary genre for being "the literature of what if" in Bainbridge's term (1986). It could also consider its subgenres, such as hard science fiction (e.g. H.G. Wells' [When] the Sleeper Awakes or Modern Utopia), soft science fiction (e.g. Philip K. Dick's novels), New Wave, and fantasy (22), which can be used as a critical tool of architectural literary analysis. Finally, of Ballard's 18 novels and 123 stories, Concentration City (1957), Chronopolis (1962), Billenium (1962), The Subliminal Man (1967) and The Ultimate City (1978), Running Wild (1989), Cocaine Nights (1996), Super Cannes (2000), Milennium People (2003) and Kingdom Come (2006) could all be analyzed as instruments for architectural literary analysis.

\section{REFERENCES}

ANTONIADES, A.C. (1992) Poetry and Literature, Poetics of Architecture, Van Nostrand Reinhold, New York.

BAINBRIDGE, W.S. (1986) Dimensions of Science Fiction, Harvard University Press, Cambridge, Massachussets.

BALLARD, J.G. (1975) High Rise, Carroll \& Graf Pub, New York.

BALLARD, J.G. (1984) Interview by Graeme Revell, Re-Search (8/9) 44.

BALLARD, J.G. (1985) Concrete Island, Vintage Books, New York.

BALLARD, J.G. (1996) A User's Guide to the Millenium, Picador, New York.

BALLARD, J.G. (2008) Miracles of Life. Shanghai to Shepperton: An Autobiography, Fourth Estate, London.

BARLAS, A.M. (1998) Resistance to An Enmity: The Street Against CIAM, METU Journal of the Faculty of Architecture 18(1-2) 25-36.

BARLAS, A.M. (2006) Urban Streets and Urban Rituals, Middle East Technical University, Ankara.

BERMAN, M. (1988) All That is Solid Melts into Air-The Experience of Modernity, Penguin Books, Baskerville.

BRYDEN, I. (2012) There are Different Ways of Making the Streets Tell: Narrative, Urban Space and Orientation, Writing the Modern City: Literature, Architecture and Modernity, eds S. Edwards, J. Charley, Routledge, London; 213-26.

BOYER, M.C. (2010) Le Corbusier, Hommes de Lettres, Princeton Architectural Press, New York.

CARMONA, M., TIESDELL, S., HEATH, T., OC, T. (2010) Public Places Urban Spaces, The Dimensions of Urban Design, Architectural Press, Oxford.

CARMONA, M. (2010) Contemporary Public Space: Critique and Classification, Part One: Critique, Journal of Urban Design 15(1) 12348 . 
FRISBY, D. (2003) Straight or Crooked Streets? The Contested Rational Spirit of the Modern Metropolis, Modernism and the Spirit of the City, ed. I.B. Whyte, Routledge, New York; 57-84.

GASIOREK, A. (2005) JG Ballard (Contemporary British Novelists), Manchester University Press, Manchester and New York.

GEHL, J. (1987) Life between Buildings. Using Public Space, Van Nostrand Reinhold, New York.

GOLD, J.R. (1997) The Experience of Modernism. Modern Architects and the Future City, 1928-53, E\&FN Spon, London and New York.

GRAFE, C., HAVIK, K., MAASKANT, M., eds. (2006) Architecture and Literature. Reflections/Imaginations, OASE (70), NAI Publishers, Rotterdam.

GRILLNER, K., HUGHES, R. (2006) Room within a View: A Conversation on Writing and Architecture, Architecture and Literature. Reflections/ Imaginations, eds. C. Grafe, K. Havik, M. Maaskant, OASE (70), NAI Publishers, Rotterdam; 56-70.

HALLIDAY, M.A.K. (1978) Language as Social Semiotic. The Social Interpretation of Language and Meaning. Edward Arnold Publishers Ltd., London.

HAVIK, K. (2006) Lived Experience, Places Read: Toward an Urban Literacy. Architecture and Literature. Reflections/Imaginations, eds. C. Grafe, K. Havik, M. Maaskant, OASE (70), NAI Publishers, Rotterdam; 37-50.

HAVIK, K. (2014) Urban Literacy: Reading and Writing Architecture, NAI Publishers, Rotterdam.

JACOBS, J. (1992) The Death and Life of Great American Cities, Vintage Books, New York.

JACOBS, A., APPLEYARD, D. (1987) Toward an Urban Design Manifesto, Journal of the American Planning Association (53) 437-47.

KALLUS, R. (2001) From Abstract to Concrete: Subjective Reading of Urban Space, Journal of Urban Design 6(2) 129-50.

LE CORBUSIER (1967) The Radiant city: Elements of a Doctrine of Urbanism to be Used as the Basis of Our Machine-age Civilization, Orion Press, New York.

LE CORBUSIER (1987) The City of To-morrow and its Planning, Dover Publications, New York.

LE CORBUSIER (2007) Toward an Architecture, trans. J. Goodman, The Getty Research Institute, Los Angeles.

LEVINE, N. (2003) Introduction to "The Death of the Street", Modern Architecture and Other Essays, ed. V. Scully, Princeton University Press, Princeton; 120-1.

MALMGREN, C.D. (1991) Worlds Apart. Narratology of Science Fiction. Indiana University Press, Bloomington and Indianapolis.

MEREDITH, J.R. (2003) Sprawl and the New Urbanist Solution, Virginia Law Review 89(2) 447-503.

MUMFORD, L. (1953) The Highway and the City, Hartcourt, Brace \& World Inc., New York. 
PETERSON, S.K. (1980) Space and Anti-Space, Harvard Architectural Review: Beyond the Modern Movement, MIT Press, Cambridge, Massachusetts; 89-90.

PRINGLE, D., (1984). J. G. Ballard- A Primary and Secondary Bibliography, G.K. Hall \& Co., Boston and Massachusetts.

SAATÇİOĞLU, E. (2002) Alternate Realities in Ursula K. Le Guin's City of Illusions, Rocannon's World, Planet of Exile, and The Left Hand of the Darkness, unpublished Master's Thesis, Institute of Social Sciences, Dokuz Eylül University, İzmir.

SCULLY, V. (1986) Modern Architecture. The Architecture of Democracy, George Braziller, New York.

SCULLY, V. (2003) Modern Architecture and Other Essays, Princeton University Press, Princeton.

SELLARS, S. (2009) Stereoscopic Urbanism: JG Ballard and the Built Environment, Architectures of the Near Future, ed. N. Clear, Architectural Design-Special Issue 79(5) 82-7.

SHONFIELD, K. (2000) The Use of Fiction To Reinterpret Architectural and Urban Space, Intersections, eds. I. Borden, J. Rendell, Routledge, London; 296-320.

SPURR, D. (2012) Architecture and Modern Literature, The University of Michigan Press, Ann Arbor.

STEIN, S., HALDENBAY, E., ROTH, E. (1990) New Directions in Architectural Research, Proceedings of the 1990 Canadian Symposium on Architectural Research, eds. J.A. Love, T.G. Lee, May 10-12, University of Calgary, Calgary; 12-26.

STEPHENSON, G. (1991) Out of the Night and into the Dream, Greenwood Press, New York.

TAFURI, M. (1979) The Disenchanted Mountain: The Skyscraper and the City, The American City: From the Civil War to the New Deal, eds. G. Ciucci, F. Dal Co, M. Manien-Elia, M. Tafuri, MIT Press, Cambridge, MA; 389-503.

TAYLOR, J.S. (2002) The Subjectivity of the Near Future: Geographical Imaginings in the Work of JG Ballard, Lost in Space, eds. R. Kitchin, J. Kneale, Continuum, London and New York; 90-103.

THOMSON, S. (1996) Places Within and Without: Memory and Literary Imagination, and the Project in the Design Studio, Memory and Architecture, ed. E. Bastea, University of New Mexico Press, New Mexico; 317-30.

TRANCIK, R. (1986) Finding Lost Space: Theories of Urban Design, Van Nostrand Reinhold, New York.

TUTAŞ, N. (2006) Yazınsal Metinlerde Biçembilimsel İnceleme, Littera (19) $169-73$.

TÜMER, G., (1981) Mimarlikta Edebiyattan Neden ve Nasıl Yararlanmalı? (Aragon'un Paris Köylüsü Üzerine Bir Örnekleme), Ege University, İzmir.

TÜMER, G. (1997) İnsan-Mekan İlişkileri ve Kafka, Sanat-Koop Yayınları, İzmir. 
Alınd1: 29.10.2013; Son Metin: 05.11.2015

Anahtar Sözcükler: Mimarlık araştırmaları; yazınsal kurgu; yazınsal çözümleme; disiplinlerarası araştırma; sokağın ölümü; kayıp mekân; Roger Trancik; J.G. Ballard; High Rise; Concrete Island.
UZ SÖNMEZ, F. (2014) Mekanın Yazınsallığı ve Bir Taşkışla Deneyimi. [http://www.boyutpedia.com/default ID 1597 aID 67214 link m ekanin_yazinsalligi_ve_bir_taskisla_deneyimi.html] Access Date (23.08.2014).

VIRILIO, P. (1984) The Overexposed City, Architecture Theory since 1968, ed. K.M. Hays, MIT Press, Cambridge MA; 540-51.

WOUDSTRA, J. (2000) Corbusian Landscape: Arcadia or No-man's-land? Garden History 28(1) 135-51.

Architexture 2008: Textual and Architectural Spaces (2015) [http://iawis. org/architexture-2008-textual-and-architectural-spaces/] Access Date (15.07.2015).

The Laboratory of Literary Architecture (2015) [http://lablitarch.com/] Access Date (30.08.2015).

Writing a Literary Analysis (2014) [https://owl.english.purdue.edu/owl/ resource/697/1/] Access Date (10.08.2014).

Writing a Literary Analysis Paper (2014) [http://www.germanna.edu/tutor/ handouts/english/literary_analysis.pdf] Access Date (10.08.2014).

\section{MIMMARI YAZINSAL ÇÖZÜMLEME: “SOKAĞIN ÖLÜMÜ”NÜN BALLARD YAZINI VE “KAYIP MEKÂN" ARACILIĞIYLA OKUNMASI}

Bu çalışmanın temel amacı, mimarlık ve edebiyat arasındaki olası ilişkinin boyutlarını ortaya çıkarmak ve mimarlık eğitimi, araştırmaları, uygulaması ve diğer disiplinler için potansiyel yararlarını örnekleyerek tartışmaktır. Çalışmanın yöntemi, yazınsal metinlerdeki mekânsal kurgu tasvirleri ve ipuçlarından yola çıkıp çeşitli mimari konuların "yazınsal çözümlemesi" üzerine kurulmuştur. Bu kapsamda, çalışma, örneklem olarak bilim kurgu yazarı Jim Graham Ballard'ın High Rise ve Concrete Island adlı iki romanına odaklanmaktadır. Buna paralel olarak mekânsal boyutu temsilen, Le Corbusier'nin modernist önermesi "sokağın ölümü" ve Roger Trancik'in "modern kentsel mekân" üzerine geliştirmiş olduğu "kayıp mekân" eleştirisi seçilmiştir. Bu anlamda hem "kayıp mekân" hem de Ballard romanları, "sokağın ölümü" üzerine paralel eleştiriler olarak çalışılmıştır. High Rise (Gökdelen), kayıp mekânı çok katlıların oluşturduğu peyzaj olarak, Concrete Island (Beton Ada) ise otoyol kenarları ve otopark alanları olarak tartışmaktadır. Bu çalışma, bu romanlardaki mimari mekân temsillerinin, Trancik'in, modernleşmenin kentsel ölçekteki sonuçları üzerine geliştirdiği eleştirisiyle paralel olduğunu önermektedir. Sonuç olarak, bu çalışma, yazınsal kurgunun mimarlık disipliniyle olan ilişkisini, bir okuma ve araştırma yöntemi olarak da "mimari yazınsal çözümleme" yöntemini ve bunun hem mekânsal hem de diğer disiplinler için katkılarını tartışarak ortaya koymaktadır. Çalışmada modernist ilkelerin kentsel mekâna olan etkileri bu yazınsal örnekler üzerinden tartışılmakta, yazınsal çözümlemenin mimarlık disiplini için eğitim, kuram, uygulama alanları gibi daha geniş çerçevede bir yöntem olarak kullanılabileceğini 
ve akademisyen ya da mimar olmayan topluluklara ulaşarak mekânsal farkındalık yaratması açısından da etkili olduğu önerilmektedir.

ZEYNEP TUNA ULTAV; B.Arch, M.Arch., PhD.

She received B.Arch and M.Arch in architecture from METU; and Ph.D. in architecture from Gazi University. She taught at Izmir University of Economics, the Department of Interior Architecture and Environmental Design between 2004 and 2014. Currently she is an assistant professor and Head of the Department of Interior Architecture and Environmental Design at Yaşar University. zeynep.tunaultav@yasar.edu.tr

T. Nur ÇAĞLAR; B.Arch., M.A., PhD.

She studied architecture at ADMMA, Department of Architecture. She received her M.A. degree in 1986 and her Ph.D. degree from Department of Landscape Architecture in Ankara University in 1992. She taught at Gazi University, Department of Architecture between 1992 and 2011. She is the Founder Head to Department of Architecture in TOBB University of Economy and Technology. ncaglar@etu.edu.tr

S. Bahar DURMAZ DRINKWATER; B.Arch., M.UD., PhD.

She is an architect who has experience in teaching, research and architectural practice. She has a PhD in Architecture from the University of Nottingham and Master of Urban Design from Izmir Institute of Technology. Her research is focused on urban architecture, public place, environmental psychology and also earthquake resistant urban environments. Currently she is an assistant professor and Head of the Department of Architecture at Izmir University of Economics. bahar.durmaz@ieu.edu.tr 